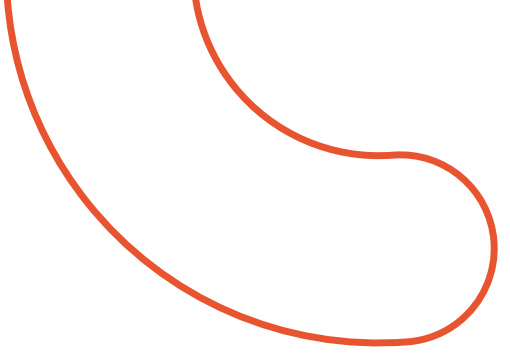

\title{
Coding's process of a microcosmos of the Historical Museum of Londrina by means of design thinking and design of exhibitions
}

\begin{abstract}
Ana Paula Perfetto Demarchi
Universidade Estadual de Londrina

perfetto@sercomtel.com.br
\end{abstract}

Cleuza B. R. Fornasier

Universidade Estadual de Londrina

cleuzafornasier@gmail.com

Júnior Yuki Morimoto

Universidade Estadual de Londrina

juniormori@uel.br

PROJËTICA

\section{COMO CITAR ESTE ARTIGO:}

DEMARCHI, Ana Paula; FORNASIER, Cleuza B.R.; MORIMOTO, Junior Yuki. Tenkuä. Coding's process of a microcosmos of the historical museum of londrina by means of design thinking and design of exhibitions. Projética, Londrina, v. 11, n. 3, p. 130-148, Nov. 2020. Edição especial FDaP.

DOI: 10.5433/2236-2207.2020v11n3esp.p130 
ABSTRACT: The article proposes to develop innovation through the coding process of communication by visuality using the exhibition design to share/clarify knowledge, avoiding and eliminating deficiencies in the acquisition of knowledge. The design thinking approach used to raise knowledge about a microcosm of the permanent room of the Historical Museum of Londrina, through the analysis of the scenario and its artifacts, so that history is learned, told and humanized, seeking the Innovation in the representation of knowledge in order to verify the knowledge acquired by visitors. The research is qualitative of exploratory nature, based in visitor's interviews and observations from groups of students visiting the museum. This have the objective to understand whether they acquired the desired knowledge, then propose collaborative solutions by the use of the DTKBoard system, based on design thinking and by the introduction of the precepts of the exhibitions design in order to improve the communication of culture and knowledge of the period related to the microcosm chosen. During the project, was identified the needs of change in the representations of knowledge and ask for the insertion of humanization to create empathy with the visitor. The research is in the validation phase of the prototypes developed with the insertion of the exhibition design and the humanization generating changes in the microcosm for the participation and validation of the target audience, for later implementation.

Keywords: Exhibition design. Design thinking. Graphic design. Learning.

\section{INTRODUCTION}

The object of study is the Historical Museum of Londrina. Museum is "a permanent institution [...] who acquires, preserves, investigates, disseminates and exposes the tangible and intangible witness of humanity and its surroundings, for education, studies and treat" (ICOM, 2007), thus the teaching process in museum 
exhibitions is important. The sender (the museum) has responsibility in this process, because the transmission channel must be efficient and adapted to the individual needs of the receiver (the public) so that there is success in the dissemination of the message.

Every museum has as institutional function to be the place, the instrument, the support of memories, but also offers the possibility of research, experimentation, interpretation or visualization of material goods and research of history, because it puts visitors in contact with history, traditions and values, contributes to the formation and awareness of one's own identity. When you rescue historical time, you intend to relive facts or reconstitute aspects of the past to make you think. The inserted objects do not always have economic value, but value attributed to the testimonies they have passed in the past (BREFE, 2005), allow to experience other times, compare with the current time and imagine a new one (MERLO, 2015).

The Historical Museum of Londrina, it has as mission to rescue, preserve and disseminate the cultural heritage of Londrina (UEL, 2018), the marks of colonization and artifacts that were part of the daily life of the families of the pioneers. In one of the rooms are exposed these objects in different microcosms, which represent important scenarios of the origin of Londrina. However, over time they suffered physical wear and the insertion of other unplanned objects, which shows that it is still looking for adjustments and complements.

Some microcosms are not upsetting the need for the most frequent attendance, the groups of elementary school students and their teachers, because the spaces surrounding them are small and do not give visibility to all exposed objects. For that reason it is difficult to create a link between visitors and the museum as a place of reflection, which can interfere in the perpetuation of the visitor's mental image and consequently in non-learning.

The Museum, which despite having a project already underway to renew and enhance the exhibition of a microcosm, lacks of improvements in the process 
of apprehension of the content of the above. In addition, museum staff also lack physical and financial supports to create visual and spatial solutions that make exhibitions easy to understand and attractive. To this end, this project suggests using the knowledge of Exhibition Design, which

“[...] it seeks to organize materially and visually the physical space, with the objective of establishing a dialectical relationship between the knowledge that the public already has on the subject on the agenda and the new knowledge that the exhibition proposes". (CURY, 2006 apud CARDOSO et al., 2012, p. 2573)

Thus, solutions are sought to know what it wants to be counted, how it will be counted and what is expected to achieve with what is counted (FERNÁNDEZ; FERNÁNDEZ, 2006). To achieve this purpose it was used the methodologies of some authors of Exhibition Design and Design Thinking as a way to add knowledge and contribute to the creation of an environment conducive to learning, the research sought to validate what has already been proposed and add new tools to make the process more effective.

The aim of this article is to demonstrate the design thinking process applied in the Historical Museum of Londrina, to introduce innovation, initially in a microcosm, correcting possible flaws in the communication process and adding knowledge of the Design of Exhibitions. In this article, the authors will demonstrate, the immersion stage, the creation, and presented until the first prototypes for validation.

The Historical Museum is important for the history of the city and region. In addition to encouraging the valorization of local culture, it is also a place of learning for several audiences, especially children (6 to 12 years). To enhance their communication when telling stories, spatial, visual and informational planning is necessary for the receiver to succeed in the apprehension of the knowledge exposed. Exhibition Design is a key part in the intermediation between the exhibition and the public because it creates an inviting functional and aesthetic interface. 


\section{THE MUSEUM AND DOCUMENTARY EXPOGRAPHY}

The International Council of Museums (ICOM, 2017), defined museum as being "a non-profit institution, permanent, at the service of society and its development, open to the public, which acquires, preserves, researches, communicates and exposes the material heritage and humanity and its environment for education, study and recreation purposes." In the Brazil, by the law number $11.904,2009$, instituted the Statute of Museums, considering.

[...] museums, for the purposes of this Law, are the non-profit institutions that conserve, investigate, communicate, interpret and expose, for the purposes of preservation, study, research, education, contemplation and tourism, sets and collections of historical value, artistic, scientific, technical or any other cultural nature, open to the public, at the service of society and its development (IBRAM, 2017).

They are different in shape, but not in content. The functions of museums are different and dependent on the approach, but the social function is inherent to all, as they contribute to individual and collective development.

Ethnographic Museum highlights and disseminates a set of practices and knowledge they made, and are part of the identity of a set of people. If, on the one hand, some knowledge will still be present in society, others may be known to a minority or even have been abandoned and forgotten (ASENSIO et al., 2012).

They can be more than spaces of objects of artistic, cultural and socioeconomic memories, but of transmitting knowledge of material and immaterial culture critically. Historical museums have a collection referring to history and its representation, primarily referring to the exponents of history, linked to the chronological order of events, historical time, to relive historical facts or reconstitute the aspects of the past and make the present think.

Historical museums contribute to society knowing its own history, traditions and values through the valorization and preservation of its historical 
heritage, whether material or immaterial. Far beyond storing, they are learning spaces outside the classroom, which motivate social and collaborative learning, make learning more effective, and contribute to the development of strategic skills for the current globalized economy (OBLINGER, 2006).

Museums are spaces designed to promote constructivist learning, according to it, can only be built real understanding and knowledge that through personal experience peer discussion and reflection, contrary to the passivity of expository classes. For Wolynec (apud DEMARCHI; FORNASIER, 2018) the tendency is to consider the city as a learning space, but an important factor for planning these spaces is the profile of the current student, generation Z and Alpha. They were born using internet, learn differently, and they are constantly exposed to different virtual environments. According to Wolynec (apud DEMARCHI; FORNASIER, 2018), there is a change in the way they access and use the information, as they are not restricted to consulting and consuming the information, but create and participate. Contrary to what is thought, they value social experiences that include communication and learning. It provides for a change in learning spaces, which must suit this new user, thirsty for learning and sensory experience.

The main function of the museum is to communicate, put man before his reality (CURY, 2005), manifested in the objects that are removed from his context to be preserved, decoded, and, mainly, endowed with symbolic and cultural value. These values give meaning to the object —-making it more than just a material thing-allow man to understand the deeds of his ancestors who led reality to become what it is today.

For these values to become known, to be interpreted, reinterpreted, and shared by man, it is necessary for the object to be displayed. The exhibition is the most common form of this museological communication, because it puts the public face to face with musealium, breaking the historical and/or cultural distance between both. The channel converts the values of objects into messages and emits 
them, but also should not only be acquired by the receiver but also constructed by it. It generates an experience of interaction between museum and public, where values are constructed when the sender and receiver are located in relation to these values (CURY, 2005). This exhibition space assumes a transformative role, because it is where the meeting between the object created with the man who interacts occur, and when it does so actively, it is transformed passively, by the knowledge that is formed.

The attribution of meaning to objects can also be understood more enlarged form, because meanings can be considered as changeable attributes, not fixed. Therefore, the activities of contextualization of "representations built in the museum", understood here as the activities of exhibition and mediation between the object and the public are emphasized in relation to other activities, such as conservation, so that they can reveal the contexts in which objects were generated (DUARTE, 2013, p. 114).

Therefore, care is necessary in the assembly of exposure, in order to create an environment favorable to shared learning, studied by the expography (FIGUEIREDO, 2012). The integration of the museologists who participated in the musealization process of the objects with the Design team responsible for assembling the exhibition should occur, in the first there is the intention and in the second the solution.

\section{EXHIBITION DESIGN AND GRAPHIC DESIGN}

Museography encompasses the expography and the design of exhibitions, as in the diagram below (CURY, 2005). The practical difference between expography and exhibition design is that one involves the language of the exhibition - visitor path, supports, scenography, lighting, audiovisual - and the other refers to design 
and shape issues (FIGUEIREDO, 2018). This distinction requires interdisciplinary teams (monologues integrated with professionals from other areas). Designers are relevant in the assembly of exhibitions with regard to the exhibition design itself as shown at fig. 1 below. It builds visual narratives that provide purposeful and original experiences create strong and memorable relationships between the visitor and the content of the exhibition (SCHERER, 2012).

Fig. 1 - Museography, exhibition and exhibition design drawn by the author.

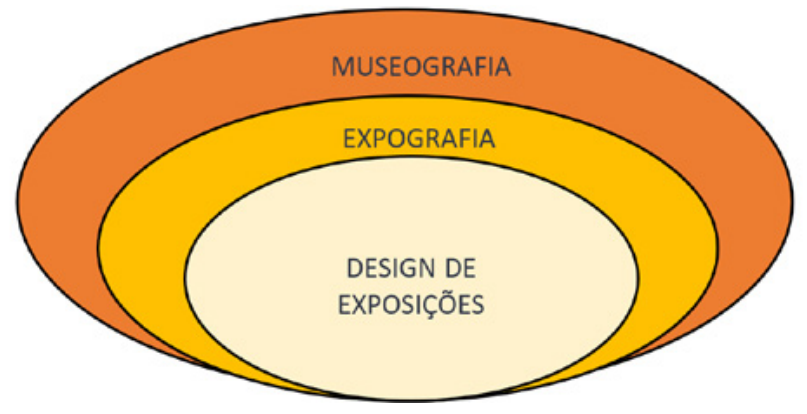

Source: Authors.

The relationship created is part of the intention of the museologists in the context of documentary expography, which reinforce "an idea, a conceptual proposal, a project to preserve patrimonial references" (CUNHA, 2005) with the musealium ${ }^{4}$. The other part, on the other hand, comes from other professionals, such as designers, who create solutions for that the intent take shape, become tangible and that causes an impact on collective subjectivity. This "gain shape" happens in several ways in the expography, specifically in the design of exhibitions, because it is the design of things, encompasses the varied subareas of design itself (fig. 2). 
Fig. 2 - Exhibition design encompasses subareas of design that help shape exposure

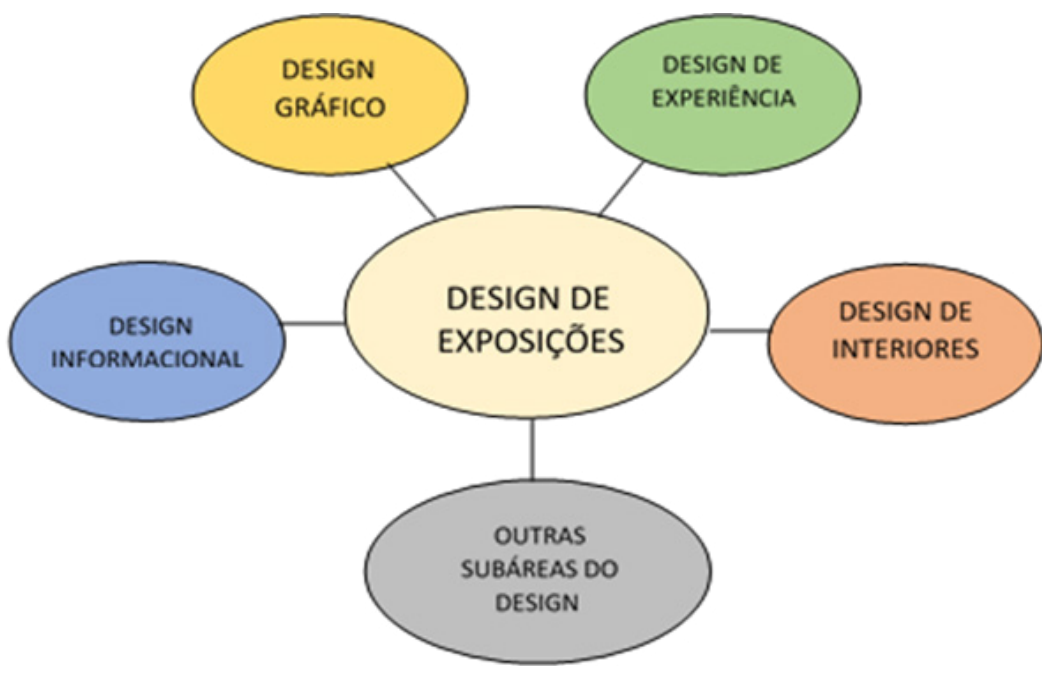

Source: Authors.

In the exhibition design, the graphic design develops the media used for object or subject information to be displayed. Typography added to visual elements such as size and color should be considered to make a positive impact on public knowledge construction and facilitate understanding of exposed artifacts.

\section{METHODOLOGICAL PROCEDURES}

It was applied the Inductive Method, which appropriates the use of general concepts because of the collection of private data, based on the experience. The qualitative aspect, supported by qualitative, non-statistical data, carries out the research method. The delineation defined was by a case study, which according to Yin (2001) is the "[...] suitable for the investigation of a contemporary phenomenon within its real context [...]". The research strategy carried out primarily by 
observations, a technique of obtaining data with more direct contact with reality, allows studying a wide variety of phenomena and examining them to obtain important discoveries (LAKATOS; MARCONI, 2003).

From the observation guide the proposal of the production of learning improvement solutions, directed by creative tools exhibited in the DTKBoard system (FORNASIER; MARTINS; DEMARCHI, 2018), which will assist in the use of the design thinking approach. Through exploratory research, it is understood the point of view of visitors and their needs, then the creative tools that facilitate problem solving (FORNASIER, MARTINS and DEMARCHI, 2018) was applied. Was used the participatory observation research for the creation and validation of microcosm's communicational improvement solutions, and organized in the DTKBoard. In the sequence, the researchers developed the hypothetical archetype (persona) and the empathy map, which empathetically involves participants to the target audience. These actions, carried out from the divergence and convergence of the designer's thinking, facilitates the dialogue of the members of the work and the internal public of the museum, so that they understand and defend the proposed changes.

The researchers will present, the first findings, to the stakeholders, when they give the feedback, it may or not be implemented. Then, with the help of one of the participatory observation strategy, the brainstorming of solutions applies, when all stakeholders will write or draw them.

\section{RESULTS AND DISCUSSION}

The microcosm chosen was the Central House, one of Londrina's first trades (fig. 3). In the first stage, was performed an analysis of the space during a visit, through observation and in a critical way, identified restrictions on the learning process offered by the microcosm. It was noticed that the texts are long, difficult to read and only in Portuguese, inefficient for foreigners and visually impaired 
people and that many objects exposed do not have information, in some cases the information is arranged on lateral plates when Object.

In the second stage, the researchers applies non-participatory observation and interviews during visits to the museum of groups of school students and their teachers. There were three days of follow-up, two schools per day with classes of the 7th year of elementary school, on average 30 students, aged between 12 and 13 years, totaling 180 students. A monitor provided by the museum guides the tours; it has the function of walking through the different microcosms explaining details, that the students not always seen. In the interview with teachers, it was clear that the visit is the introduction to the learning of the history of Londrina.

Fig. 3 - Microcosm of the Museum - Central House of David Dequech Dequech's History

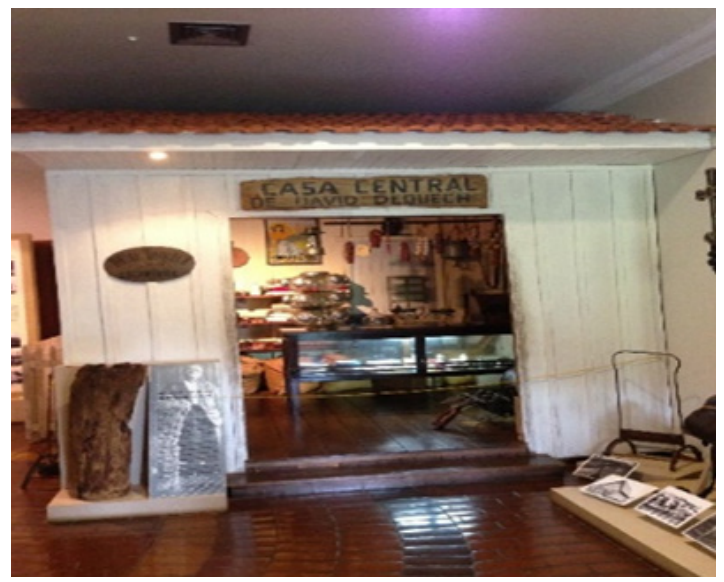

Source: Authors.

The researchers noticed that the amount of information in textual form is the biggest problem, because the most frequent audience is from a generation that grew up with internet, interactivity, and videos to tell stories. In addition, even 
if they had willing to read they would not have time to do so on a visit with marked time. It was also noticed the lack of people in the microcosm, as if they were not part of the scenario, devaluing the human being as director and centralizer of memories.

Following the participatory observation, the researchers began the completion of the first space of the system called immersion (fig. 4), where the information collected was organized and cataloged in the DTKBoard (FORNASIER; MARTINS; DEMARCHI, 2018).

Fig. 4 - Space 1 - Immersion

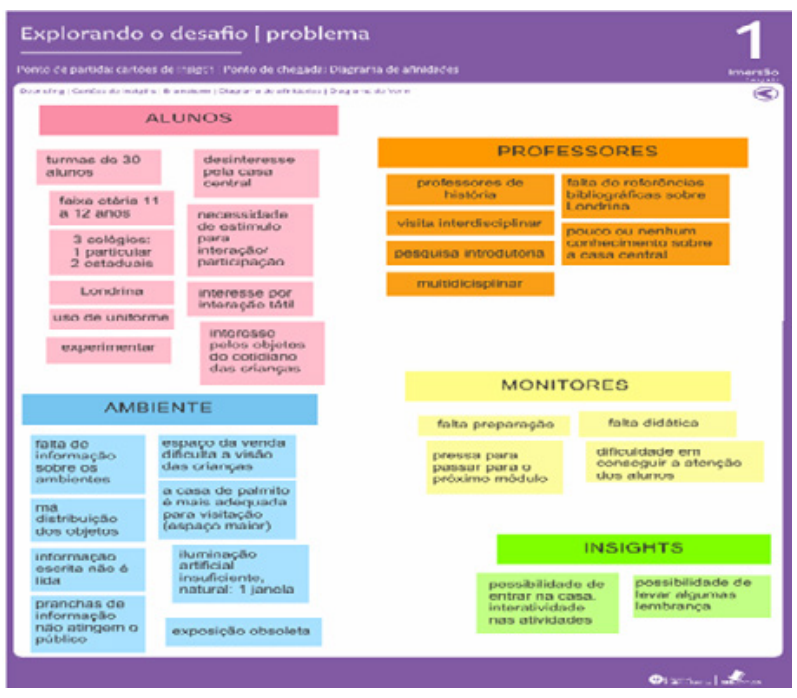

Source: Authors.

In this context, students are the target audience of the project, based on their learning needs of the history of the city. For learning to be achieved, their daily universe was understood, which characterizes them, and in what way they learn more easily. From this point, the researchers filled the second space of the tool in order to understand the public, which resulted in the formulation of a persona (fig. 5) (FORNASIER; MARTINS; DEMARCHI, 2018). 
Fig. 5 - Space 2 - Tool 2a - Understanding persona and 2b Understanding empathy map.
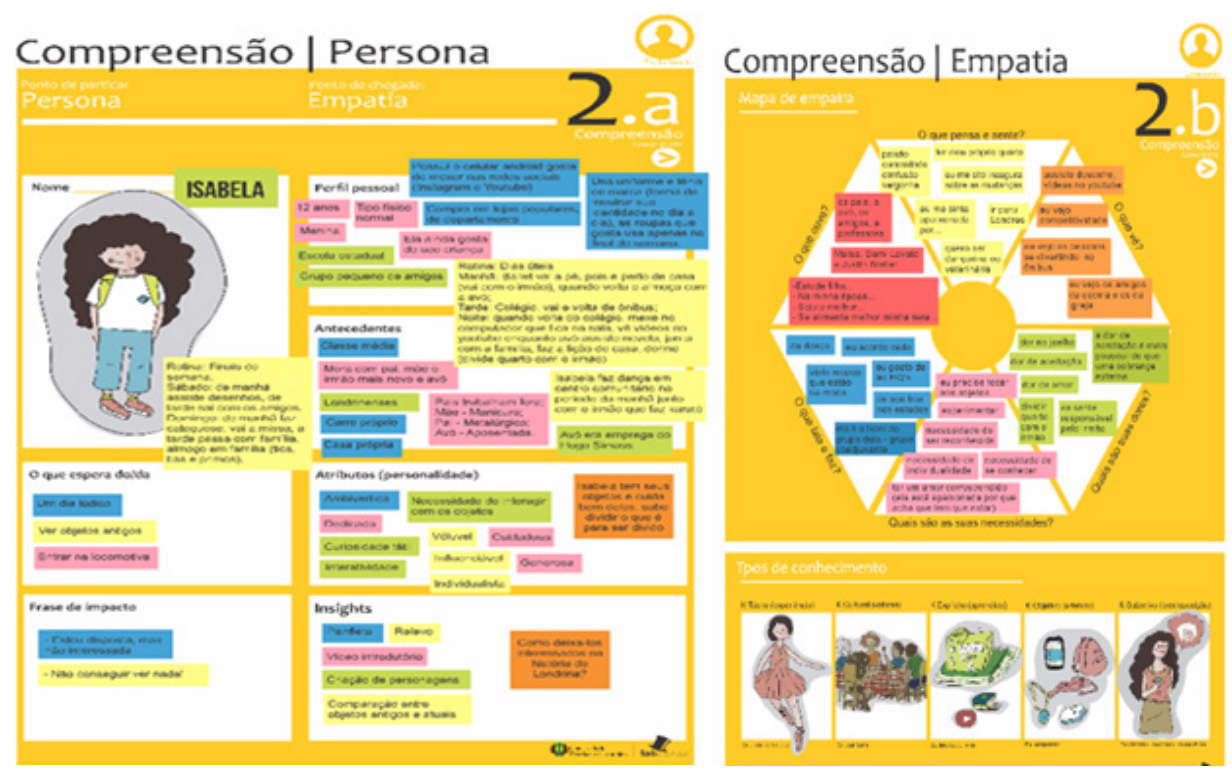

Source: Authors.

Although the information brings a rich scope, there is a need to know the daily life of the persona, understand it to serve it better; the empathy map was used (fig. 5 above). Then the researchers held a new meeting with the teams and all the new activities developed them were presented to the museum collaborators. The third space of the DTKBoard tool (Fig. 6) started, which consisted of mentally analyzing what the researchers presented so far, and then all stakeholders should draw or write ideas that they think be viable to be included in the Microcosm.

After this space, the group developed a prototype (fig. 7) that they will validate by the target audience and stakeholders in order to capture the perceptions of visitors, from these contributions the researchers will made changes in the microcosm. 
Fig. 6 - Space 3 - Creation

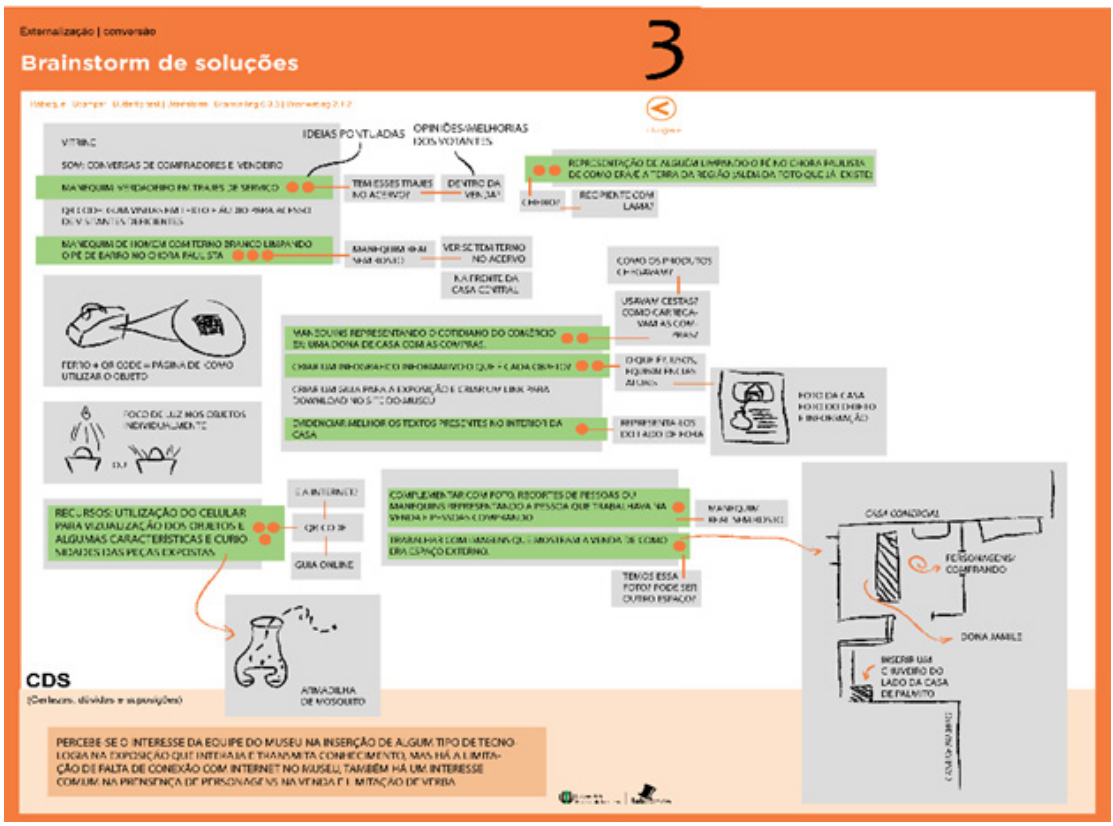

Source: Authors.

Fig. 7 - Space 4 - Prototype

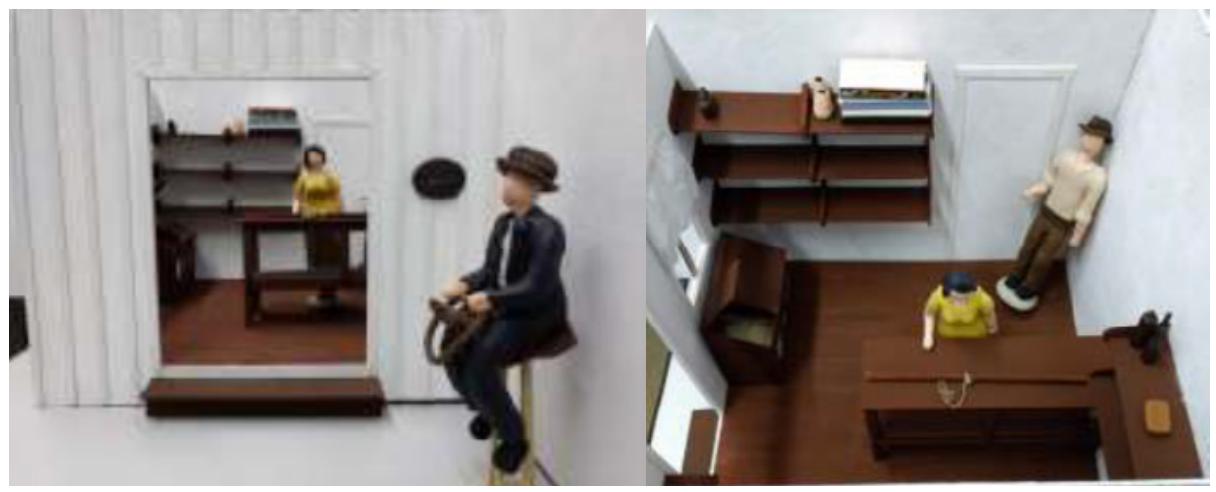

Source: Authors. 
One of the prior changes was to include people in interaction with space, which are in the prototyping phase on a human scale with costumes of the period. At the suggestion of the museum's stakeholders, explanatory panels were also developed, which encode the information exposed in a simplified and playful way using the exhibition design that in this space begins to be used in the work, and the researchers inserted images to create the ambience of space and improve empathy, facilitating the learning by the visitors.

\section{CONCLUSION}

The development of the project is in the stage of the research strategy, in which the researchers used the observation of the space to define the problem, which is why the researchers in the technical visit needed to understood very well and deeply the public, that in this case, are children accompanied by their parents or on school excursions. The Museum as a learning space, where one learns from the social experience and discussion between peers, for this, the exhibition has to generate moments of reflection itself, interactions with objects and history account. Unfortunately, the distancing of the public to objects and by the non-recognition of these hinders or does not generate this reflection.

It is noteworthy that what makes difficult the learning about the Microcosm of the Central House is the lack of space for a group the 30 students to have the visualization of the objects that are inside. The story told about space does not have to be long, but interactive, unfortunately, the way objects and texts are arranged in the exhibition generates the dispersion of students who cannot see them and link them with the story told.

The researches perceived that the exposed objects, that caught the attention, were those that students know derivations either by function or by 
formal similarity to ones current in their lives. Those who drew attention directly or indirectly were the iron, the sewing machine, the sweet case, ceramic dishes and beer keg to be bottled, which they seen in cartoons. It is important emphasized that the child who mentioned the barrel was one of those who was on one of the steps in front of the entrance door during the explanation of the monitor. It is warned that objects that contemplate similarity exposed in the current exhibition and have not been pointed out are, because they are far from the point of view. Objects very different from the current ones need to be relocated, others need to be removed, as well, as there is a need humanization of space so that the public can create empathy and learn.

The stakeholders are interested in the changes, mainly because they participate in it, which demonstrates the importance of their inclusion in the process, for the acceptation and assistance in the introduction of the changes. The researchers also intended to strengthen the involvement of visitors in the phases to come. Further research should also occur to verify that the level of learning increased; to only then, introduce similar changes in the other microcosms.

The use of Design Thinking assists in planning and can help optimize learning in this and other microcosms of the Historical Museum of Londrina. In addition, to became a learning space of the history of the city, traditions and values, and contribute more and better in the formation and awareness of the very identity of local society and citizens of the future. 
Projética, Londrina, v. 11, n. 3 Esp IFDaP, p. 130-148, novembro 2020

\section{REFERENCES}

1. ASENSIO, Mikel; POL, Elena; ASENJO, Elena; CASTRO, Yone (ed.). Nuevos museos, nuevas sensibilidades. Madrid: Universidad Autónoma de Madrid, 2012. (SIAM - Series Iberoamericanas de Museología, año 3, v. 4). Available in: https://sites.google.com/site/mikelasensiobrouard/iii-siam. Access in: 5 Jun. 2020.

2. BREFE, Ana Cláudia Fonseca. O museu paulista: Affonso de Taunay e a memória nacional. São Paulo: UNESP/Museu Paulista, 2005.

3. CARDOSO, Eduardo; CATTANI, Airton; COSSIO, Gustavo; SCHERER, Fabiano. Contribuição para o ensino de metodologia em Design de Exposição. In: CONGRESSO BRASILEIRO DE PESQUISA E DESENVOLVIMENTO EM DESIGN, 10., 2012, São Luís. Anais [...]. São Luís: EDUFMA, 2012. p. 2572-2584.

4. CUNHA, Marcelo Bernardo. Exposições museológicas como estratégias de comunicação. In: SEMINÁRIO: EXPOSIÇÕES MUSEOLÓGICAS COMO ESTRATÉGIAS DE COMUNICAÇÃO, 2005, Lisboa. Anais [...]. Lisboa: Universidade Lusófona de Humanidades e Tecnologia, 2005. p. 1-23.

5. CURY, Marília Xavier. Exposição: concepção, montagem e avaliação. São Paulo: Annablume, 2005.

6. DEMARCHI, Ana Paula Perfetto; FORNASIER, Cleuza Bittencourt Ribas. O uso do design thinking em um microcosmos do museu de londrina para a melhoria da aprendizagem. In: ENCONTRO NACIONAL DE PESQUISA EM CIÊNCIAS DA INFORMAÇÃO, 19., 2018, Londrina. Comunicação oral (pt-BR)

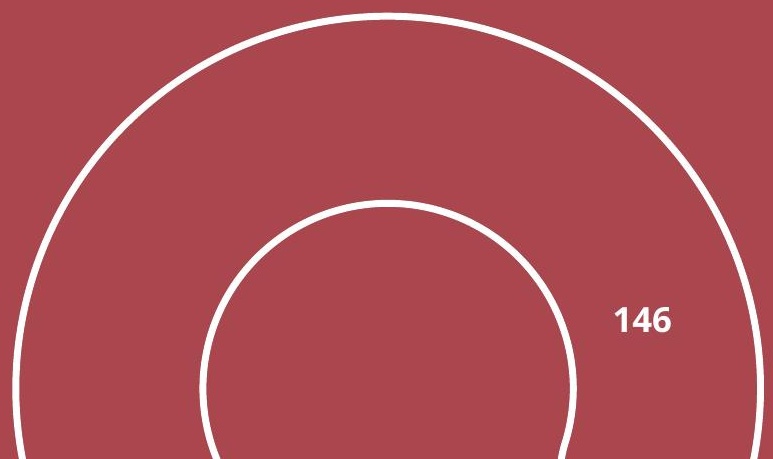


3 [...]. Londrina: UEL, 2018. Tema: Gt-2 - Organização e Representação do Conhecimento.

7. DUARTE, Alice. Nova museologia: os pontapés de saída de uma abordagem ainda inovadora. Museologia e Patrimônio, Rio de Janeiro, v. 6, n. 1, p. 99-117, 2013.

8. FIGUEIREDO, Renata. O que é expografia? 2012. Available in: https:// criticaexpografica.wordpress.com/2012/05/25/o-que-e-expografia/. Access in: 5 Jun. 2018.

9. FORNASIER, Cleuza Bittencourt Ribas; MARTINS, Rosane Fonseca de Freitas; DEMARCHI, Ana Paula Perfetto. Produção e incorporação do design para inovação baseado no processo de design thinking: sistema DTKboard. In: MARTINS, Rosane F. F.; CERQUEIRA, Vicente (org.). Design para inovação: conceitos, proposições e casos no Brasil. São Paulo: Rio Books, 2018.

10. IBRAM- Instituto Brasileiro dos Museus. O que é museu. 2017. Available in: http://www.museus.gov.br/os-museus/o-que-e-museu/. Access in: 5 Jun. 2018.

11. ICOM - International Council of Museums. Definições. Available in: http:// icom.museum/la-vision/definicion-del-museo/L/1/. Access in: 5 Jun. 2018.

12. LAKATOS, Eva Maria; MARCONI, Marina Andrade. Fundamentos de metodologia científica. 5. ed. São Paulo: Atlas, 2003.

13. MERLO, Márcia (org.). Memórias e museus. São Paulo: Estação das Letras e Cores, 2015. 
